ANALES DE LA UNIVERSIDAD DE ALICANTE. HISTORIA MEDIEVAL, N. ${ }^{\circ}$ 16, (2009-2010) (pp. 63-91) I.S.S.N.: 0212-2480

\title{
PODER PATRICIO E IDENTIDAD POLÍTICA EN BURGOS
}

\author{
Yolanda Guerrero Navarrete $e^{1,2}$ \\ Universidad Autónoma de Madrid
}

\section{RESUMEN}

El poder urbano es, por definición, un poder proteico en donde conviven diferentes instancias de poder que no necesariamente deben componer una nítida pirámide jerárquica. Es indudable un reconocimiento de una cierta jerarquía de poderes, en donde la cúspide pertenece al rey, pero en Burgos, concretamente, el monarca se ve obligado a pactar, sobre todo en los difíciles y críticos reinados de Juan II y Enrique IV. Patriciado, vecindades, clero, nobleza e incluso oficiales regios constituyen no tanto un «apilamiento institucional», como un «alineamiento», que implica una permanente y constante dialéctica de tensión y distensión, con la identidad e integridad del poder concejil y los privilegios y libertades que lo preservan y afianzan, como telón de fondo y principal argumento político. De todos estos poderes, el único que es intrínsecamente urbano, que se define como tal, es el concejil, o lo que es igual en la Baja Edad Media, el poder patricio. Si existe un rasgo que defina a la ciudad bajomedieval ese es la génesis de un sistema de poder eminentemente urbano, cuya producción y reproducción requiere del marco y de la lógica urbana y que, en definitiva, es el que permite a las ciudades singularizarse frente al resto de los poderes feudales.

Palabras clave: Identidad política urbana, Burgos, Baja Edad Media.

1 Doctora en Geografía e Historia. Catedrática de Universidad. Facultad de Filosofía y Letras. Departamento de Historia Antigua, Historia Medieval, Paleografía y Diplomática. Universidad Autónoma de Madrid. 28.049. Madrid .Ce.:yolanda.guerrero@uam.es.

2 Este trabajo ha sido realizado en el marco del proyecto de investigación de I+D financiado por el Ministerio de Ciencia e Innovación ( ${ }^{\circ}$ de referencia, HAR2009-08946), dirigido pro la Dra. Yolanda Guerrero Navarrete y titulado, Fundamentos de identidad política: la construcción de identidades políticas urbanas en la Península. 


\begin{abstract}
The urban power is, by definition, a protein power in where coexists different instances from power which not necessarily they must compose a clear hierarchic pyramid. A recognition of a certain hierarchy of powers is doubtless, in where the peak belongs to the king, but in Towns, concretely, the monarch is itself forced to agree, mainly in the difficult and critical reigns of Juan II and Enrique IV. Oligarchy, vicinities, clergy, nobility and even officials regal constitute not as much «piling up institutional», like «alignment», that implies permanent and constant dialectic of tension and a distension, with the identity and integrity of the municipality power and the privileges and liberties that preserve it and strengthen, like drop curtain of bottom and main political argument. Of all these powers, the only one which he is intrinsically urban, that is defined as so, is the municipality. If a characteristic exists that defines to the low-medieval city that is the consolidation of a system of being able eminently urban, whose production and reproduction require of the frame and the urban logic and that, really, he is the one that allows the cities to distinguish itself as opposed to the rest of the feudal powers. Throughout the low-medieval centuries Towns, like most of the Castilian, peninsular or European cities, it has been constructing his political identity through three parallel and simultaneous processes: the consolidation of the system of being able oligarchy, the political minting of the intrinsic identity characteristics to he himself and its manifestation through gestures and attitudes or, among other things, of the consolidation of an institutional and ceremonial language. My objective is to analyze this triple process in Towns.
\end{abstract}

Keywords: Identity politic urban, Burgos, Low Middle Age.

A lo largo de los siglos bajomedievales Burgos, al igual que la mayoría de las ciudades castellanas, peninsulares o europeas, ha ido construyendo su identidad política a través de tres procesos paralelos y simultáneos: la consolidación del sistema de poder patricio, la acuñación de los rasgos identitarios intrínsecos al mismo y su externalización a través de gestos y actitudes políticas o, entre otras cosas, de la génesis de un lenguaje institucional y ceremonial. Mi objetivo es analizar este triple proceso en Burgos.

A finales de la Edad Media las autoridades urbanas buscan persistentemente una ciudad más bella y más apacible a la convivencia, pero, sobre todo más insigne, más honorable. «Ornato» y «honra» son los dos atributos a los que constantemente hacen referencia alcaldes y regidores en Burgos. A medida que avanzan los siglos bajomedievales va perfilándose un vínculo cada vez mejor definido y más estrecho entre la ciudad y su élite, entre el «honor» de una ciudad y la «virtud» de su patriciado de forma que poder patricio e identidad política 
urbana son dos conceptos indisolublemente unidos e interdependientes. Los primeros son, como afirmaba la ciudad de Soest en la segunda mitad del siglo XII «los mejores de la ciudad, por cuya autoridad la ciudad prospera y en los que se basa la esencia del derecho y de la fortuna» ${ }^{3}$ mientras que al contribuir al ornato de aquella, «en un mundo en que el aspecto externo y las apariencias establecen códigos de valor-, defendiendo y promoviendo su honra, ennoblecen su ciudad y se ennoblecen a sí mismos, a quienes la dirigen y dominan» ${ }^{4}$.

El poder urbano es, por definición, un poder proteico en donde conviven diferentes instancias de poder que no necesariamente deben componer una nítida pirámide jerárquica. Es indudable un reconocimiento de una cierta jerarquía de poderes, en donde la cúspide pertenece al rey, pero en Burgos, concretamente, el monarca se ve obligado a pactar, sobre todo en los difíciles y críticos reinados de Juan II y Enrique IV. Patriciado, vecindades, clero, nobleza e incluso oficiales regios constituyen no tanto un «apilamiento institucional», como un «alineamiento», que implica una permanente y constante dialéctica de tensión y distensión, con la identidad e integridad del poder concejil y los privilegios y libertades que lo preservan y afianzan, como telón de fondo y principal argumento político ${ }^{5}$. De todos estos poderes, el único que es intrínsecamente urbano, que se define como tal, es el concejil, o lo que es igual en la Baja Edad Media, el poder patricio. Si existe un rasgo que defina a la ciudad bajomedieval ese es la génesis de un sistema de poder eminentemente urbano, cuya producción y reproducción requiere del marco y de la lógica urbana y que, en definitiva, es el que permite a las ciudades singularizarse frente al resto de los poderes feudales. A lo largo de los siglos bajomedievales Burgos, al igual que la mayoría de las ciudades castellanas, peninsulares o europeas, ha ido construyendo su identidad política a través de tres procesos paralelos y simultáneos: la consolidación del sistema de poder patricio, la acuñación de los rasgos identitarios intrínsecos al mismo y su externalización a través de gestos y actitudes políticas o, entre otras cosas, de la génesis de un lenguaje institucional y ceremonial. Mi objetivo es analizar este triple proceso en Burgos.

Desde mediados del siglo XIII, se detecta en el conjunto de los reinos peninsulares un doble y coincidente proceso: por un lado, una más que evidente tendencia hacia la elitización de los gobiernos urbanos y, por otro, una política monárquica destinada a legitimar e institucionalizar en las ciudades el sistema

3 Cir. Y. Barel, La ciudad medieval. Sistema social-Sistema urbano. Madrid, 1981, pp. 87

4 Ibid. Pp. 140

5 GUERRERO NAVARRETE, Yolanda (2008): «Rey, nobleza y élites urbanas en Burgos (siglo XV)». En F. Foronda y A.I Carrasco Manchado (eds.), El contrato político en la Corona de Castilla. Cultura y sociedad políticas entre los siglos X al XVI. Dikinson, Madrid 
oligárquico y el poder del patriciado urbano. En Castilla, desde los primeros privilegios concedidos a los caballeros villanos por Alfonso X, la institución del Regimiento por Alfonso XI, hasta finalmente la política de «restauración de la constunbre antygoa» de los monarcas católicos, toda la estrategia regia viene a confirmar y respaldar el monopolio del poder urbano por una reducida elite de ciudadanos, incluso como veremos después con el nombramiento de las llamadas justicias de fuera, corregidores y asistentes, generalizado en el siglo XV. Como decíamos, en este sentido, los monarcas castellanos avalaron y consolidaron las tendencias de evolución internas del sistema concejil: patrimonialización de los cargos, privatización del poder y cristalización de una conciencia estamental oligárquica, destinada a identificar a las elites y a frenar las aspiraciones del común.

Dicho proceso en Burgos se inscribe en el arco temporal de los años que transcurren entre 1345, fecha del documento regio por el que se instituye el Regimiento en Burgos ${ }^{6}$ y el 15 de enero de 1475, momento es que se promulga definitivamente la "constitución patricia» en esta ciudad ${ }^{7}$. En dicho período se asiste en la ciudad del Arlanzón a la consolidación de un específico sistema de poder. Tan sólo la enorme cantidad de años (130 en total) que abarca este proceso de consolidación nos está orientando sobre las dificultades que entrañó el mismo. Entre 1345 y 1475, primero y último -además de definitivo- éxitos de la élite, se constatan algunos momentos difíciles. El primero de ellos, el que da origen a la Sentencia Arbitral del Conde de Castro en $1426^{8}$, por el que se llega a un acuerdo institucional entre oligarquía y común que regula la participación de las vecindades en el ayuntamiento de alcaldes y regidores, sus competencias y los procedimientos a seguir en la elección de sus representantes. El segundo, el que sin traducción institucional ni documental, ve crecer el estrecho margen de maniobra de las vecindades al socaire del desgobierno y de las incertidumbres que provoca en Burgos la agitada década que se inicia en 1465, cuando regidores y alcaldes deben tomar decisiones de índole tan comprometida como la de optar por el bando del rey Enrique o del anti-rey Alfonso. En este sentido, el documento del 15 de enero de 1475 vendría a ser -como demostró en su día J.A. Pardos- la restauración de la vieja «constitución municipal pervertyda» (p. 548), la restauración del uso e costunbre antygoa.

\footnotetext{
${ }^{6}$ Publ. BONAChÍA HeRnANDO, J. A. (1978): El concejo de Burgos en la Baja Edad Media(1345-1426). Valladolid, $n^{\circ} 15$.

7 Asi la designa, creo que con acierto, PARDOS MARTíNEZ, J. A. (1985): «Constitución patricia» $\mathrm{y}$ «comunidad» en Burgos a finales del siglo XV.(Reflexiones en torno a un documento de 1475)». En La ciudad hispánica durante los siglos XIII al XVI. I. Madrid, 580. El documento está publicado con el $n^{\circ} 11$ del apéndice documental.

8 También publ. por BONACHIA HERNANDO, J. A. Op. Cit. apéndice documental no 14
} 
A lo largo de este largo proceso de consolidación del poder patricio, articulado en torno a la dialéctica intra-élites y al respaldo institucional de la Corona, se fueron acuñando los rasgos identitarios del sistema: el poder patricio concebido como un poder monopolístico, su condición de poder privado y patrimonial, que sólo así permite el control de la reproducción del poder en el seno del sistema y de su efectiva aplicación y, finalmente, la cristalización de una conciencia oligárquica y su «externalización» y traducción al conjunto de la sociedad a través de un articulado lenguaje político, ceremonial y actitudinal que reproduce la especifica percepción social del poder patricio

\section{LA DIALÉCTICA INTRA-ÉLITES Y LA CONSOLIDACIÓN DEL MONOPOLIO DEL PODER PATRICIO EN BURGOS}

Si tratáramos de reducir a su esqueleto primigenio el esquema de las relaciones de poder en Burgos en el siglo XV, descubriríamos que, como en muchas otras ciudades de la época, el discurso fundamental es el que enfrenta a las diferentes élites entre sí. Sobre esta línea argumental básica actúan, en primer lugar, la nobleza del entorno, que en ciudades como Burgos, se limita a una influencia indirecta, articulada fundamentalmente a través del clientelismo en el que indefectiblemente se hayan imbricados los hombres buenos de la ciudad, y que contribuye, en última instancia, a avivar y hacer aflorar constantemente la rivalidad entre las diversas facciones y bandos de las elites. En segundo lugar, sobre dicha línea argumental actúa sobre todo el monarca, quien sanciona permanentemente la labor de las elites de poder, estimula en ocasiones la promoción individual de ciertos elementos de las elites aspirantes e impide sistemáticamente cualquier intento de promoción y equiparación colectiva de estas últimas.

La inevitable relación poder/sociedad nos presenta en Burgos, al igual que en cualquier otro escenario, una realidad social polarizada en torno a dos grupos claramente diferenciados y objetivamente antagónicos, que tradicionalmente conocemos en las ciudades como Oligarquía y Común. La primera, minoritaria y detentadora de los resortes de poder (económicos, sociales, políticos e ideológicos), representa la clase dominante urbana; el segundo, el conjunto mayoritario de la población, agrupa, en contrapartida, a los sectores sociales dominados.

Al leer por primera vez la documentación municipal castellana en el siglo XV sorprende casi de modo inmediato la constante reiteración de ciertos apellidos. Aparecen continuamente figurando como testigos, asistiendo a las reuniones institucionales de ayuntamiento y concejo, representando y resolviendo para el mismo ciertas mandas de mayor o menor envergadura, arrendando rentas, decidiendo con su voto cuestiones fundamentales del gobierno de la ciudad o desempeñando oficios menores del concejo. Apenas son 20 ó 30 familias en cada 
ciudad, pero pronto nos damos cuenta de que comparten en cada núcleo urbano unas mismas características: una misma base de riqueza y un idéntico modo de vida. Como hemos mencionado anteriormente, el Ordenamiento de Alfonso XI por el que se instituye el Regimiento es el punto de llegada de un proceso que iniciado un siglo antes culmina con la monopolización del poder municipal por los grupos privilegiados de cada ciudad. Bien fuera el factor bélico o el factor mercantil el detonante del proceso de selección de las elites urbanas, el último cuarto del siglo XIV asiste a la instalación definitiva de estas elites al frente del poder municipal.

El conjunto de los habitantes de Burgos, al igual que el resto de los núcleos urbanos castellanos que no forma parte de las oligarquías o élites dominantes, se integra bajo la genérica denominación de común: aunque agrupa sectores socioeconómicos muy diversos (campesinos, artesanos, pequeños comerciantes, trabajadores por cuenta propia o al servicio y jornal de otros), y, por tanto, no posee una situación socioeconómica similar ni vive de la misma manera, sí se encuentran notas características que afectan a todos por igual. La más sobresaliente, sin duda, es la relativa a su apartamiento de las esferas locales de poder, a las que en la práctica tienen vedado el acceso. En realidad la noción de «común», «comunidad» nace, por un lado, del proceso de oligarquización de los gobiernos urbanos y, por otro, de la propia evolución económica de la ciudad. Fue precisamente la necesidad de garantizar ciertos mínimos de participación en los gobiernos urbanos, una vez institucionalizado el Regimiento, lo que creó entre el conjunto de pecheros apartados institucionalmente del poder una cierta conciencia de unidad que se fortalece a medida que transcurre el siglo XV a través de los casi permanentes enfrentamientos con quienes dominan en el concejo. Dicha conciencia de unidad favoreció su actuación colectiva en algunas ocasiones, y en muchos casos el mantenimiento de un órgano de reunión común.

No obstante, cualquier órgano colectivo de actuación conjunta del común permite observar una transformación decisiva en el seno de éste que afectará a su presunta representatividad, al tiempo que permite enfocar de forma diferente la conflictividad oligarquía/común: me refiero al proceso apreciable de elitización de este último. En Toledo, Astorga, Burgos, Segovia, etc. la observación de la evolución de los órganos de representatividad colectiva del común permiten constatar una importante transformación en el seno de éste desde el momento en que se perfila un sector del mismo que se alza con la dirección de la colectividad e intenta aprovecharse en beneficio propio de la actuación y reivindicaciones del conjunto.

Así, en casi todas las ciudades castellanas del período se constata la existencia de una estrecha franja de pecheros que se alza por encima del resto de sus 
compañeros de clase y se impone como sus líderes. Casi todos están reclutados entre los mercaderes y artesanos enriquecidos, por lo que muchas veces buscan sólo ampliar sus privilegios socio-económicos y acceder a porciones cada vez mayores de renta. Para controlar dicho proceso las oligarquías han venido estableciendo una serie de estrategias «oficiales» que les permiten asimilar por cauces controlados las inevitables incorporaciones de ciudadanos enriquecidos y seleccionados del entorno de la comunidad. Para ello estarían las clientelas y los oficios subalternos, sobre las que volveré más adelante, instrumentos de canalización de las aspiraciones individuales utilizados sistemáticamente por estas elites aspirantes. Sin embargo, en el siglo XV parece percibirse un grupo relativamente importante según los casos que, en parte por ser conscientes de sus necesidades e intereses prioritarios, pero también probablemente por no tener otra opción, y como respuesta a la postura obstruccionista practicada de forma sistemática por la clase superior, aspira a llegar al nivel de ésta, colocándose a su lado o desplazándola si fuera preciso y posible. Desde la perspectiva de los enfrentamientos oligarquía/común y, más concretamente, desde la certeza de que una estrecha facción de este común utiliza las movilizaciones de la comunidad para hacer valer sus propios intereses, las luchas intraurbanas del siglo XV, o al menos una gran parte de las mismas, cobran un nuevo sentido: aparecen como fruto de los intentos de este sector del común por conseguir un lugar entre o junto a los privilegiados, $\mathrm{Y}$ parece que estas pretensiones, en especial la de igualarse a ellos, se aceleran en el siglo XV.

Los distintos «matchs» de esta confrontación se desarrollan a lo largo del siglo XV y primeros años del XVI, siendo el objeto central de los mismos la figura del procurador del común. Desde comienzos del siglo se suceden los enfrentamientos en torno al nombramiento y designación de esta figura. A través del mismo, el común en su conjunto esperaba ver mejor defendidos, e incluso ampliados, sus derechos, a la vez que contenidos los abusos de sus gobernantes. Mientras, la élite del común, que lidera a este en tales conflictos, espera además imponer su personal presencia en el concejo, con lo que efectivamente empezaría a participar de ese poder que tiene monopolizado la clase dominante. Tanto ante las reuniones del concejo como ante la corte, el procurador lleva la voz y defiende los intereses del común, y muy especialmente de la élite del mismo. Pero siempre tendrá que vencer la resistencia de la oligarquía, aunque, de mejor o peor grado esta tenga que aceptar la presencia de esos procuradores del común y permitir a la larga su acceso regular al concejo, al menos cuando se trate de asuntos relacionados con los intereses de los vecinos. A medio plazo, las diversas escaramuzas que se van sucediendo darán la victoria a ese grupo intermedio que se ha formado entre la clase dominante tradicional y el común propiamente di- 
cho, si consideramos como tal que la clase emergente, la élite del común, consiga llegar al concejo bien mediante la institucionalización de los procuradores del común, bien a través de su integración individual en las filas de la oligarquía. Desde este punto de vista el resto del común será derrotado, máxime si tenemos en cuenta que los intereses de la clase dominante y los de la élite del común no están en el fondo tan encontrados. Mientras la primera sólo busca mantener su posición y mejorarla si fuera posible, la élite del común respeta esa situación y, salvo en situaciones extremas, no pretende suplantar radicalmente a la clase dominante tradicional, sino solamente participar de sus prerrogativas, compartir sus posiciones o hacerse un hueco a su lado. De ahí se deriva que en cierto modo ambos contrincantes sean derrotados. La clase dominante lo será parcialmente en el sentido de que no puede defender su posición sin aceptar a su lado a los nuevos elementos, lo que supondrá a la larga integrar en sus filas a una parte de la élite del común. Por su parte, la clase emergente debe figurar ampliamente en el lado de los perdedores, ya que, a pesar de que algunos de sus miembros logren individualmente sus objetivos, el colectivo como tal nunca los alcanza.

En Burgos dicho conflicto cuenta con un documento de excepcionalidad, al que ya me he referido, la Sentencia Arbitral del Conde de Castro, que no sólo permite seguir los términos del conflicto y del «pacto» intra-élites, sino también su seguimiento y evolución en el tiempo y cuya importancia en este sentido ya he analizado hace algunos años ${ }^{9}$. La normativa regulada por dicha sentencia, aunque generalmente aceptada, no estuvo exenta de conflictos en su aplicación en los años subsiguientes a su dictado. Superadas las dificultades iniciales, su cumplimiento suscitó al menos recelos puntuales a lo largo de todo el siglo XV: en 1429, es el nombramiento de las alcaidías de Muñó y Cellórigo las que provocan el intento de incumplimiento de la misma por parte de los regidores y alcaldes de la ciudad ${ }^{10}$. En 1435 los oficiales amenazan con que si las vecindades no nombran personas pertenecientes para los oficios, ellos designarían otras diferentes ${ }^{11}$ y, todavía en 1453 los problemas continúan, esta vez en torno al nombramiento de los fieles ${ }^{12}$.

A lo largo del siglo XV se producirá, pues, la definitiva consolidación del monopolio oligárquico del poder por parte del patriciado y, por consiguiente, la derrota definitiva de la élite del común. Durante todo el siglo XV, las luchas

9 GUERRERO NAVARRETE, Yolanda (2008): «Rey, nobleza y élites urbanas en Burgos (siglo XV)». En F. Foronda y A.I. Carrasco, El contrato politico en la Corona de Castilla. Cultura y sociedad políticas entre los siglos X al XVI. Madrid, pp. 243- 249.

${ }^{10}$ AM.B., LL.AA., 1429-30, fol. 20r

${ }^{11}$ Ibid. 1436, fol. $3 \mathrm{v}$

12 Ibid. 1453, Fol.. 25v-27v 
políticas urbanas han sido utilizadas por los bandos urbanos en liza, a la vez que dichos bandos encubrían esa lucha por el poder local que ahora nos interesa. De ahí la aparente complejidad de los conflictos intraurbanos superpuestos: la élite del común se enfrenta a la clase dominante, aprovechando muchas veces el enfrentamiento de esta con el resto del común. Por otra parte, no faltan las luchas internas que enfrentan entre sí a los distintos integrantes de la oligarquía. Y todo esto hay que añadir el conflicto que enfrenta a la monarquía y a las propias clases urbanas en una búsqueda constante de reafirmación y engrandecimiento. En efecto, los problemas políticos planteados especialmente durante el reinado de Juan II y Enrique IV provocan la división banderiza de las ciudades y permiten que al calor de estos enfrentamientos puedan desarrollarse las luchas interclasistas por el poder e incluso proporcionar pretextos al común para aprovechar las circunstancias y reclamar sus reivindicaciones.

En general, la política regia favorece ese paulatino proceso de formación de una nueva clase social, pero lo hace de una forma peculiar. Al tiempo que refuerza el control oligárquico del sistema mediante la ampliación de las competencias de alcaldes y regidores y la exclusión de otros oficiales de la toma de decisiones en Burgos (Vid. Nota ${ }^{0} 6$ ) y sanciona las decisiones de las èlites de poder mediante una consensuada política de corregidores y justicias de «fuera» ${ }^{13}$, paralelamente permite el acceso de ciertos elementos enriquecidos a las esferas -generalmente las inferiores- del poder local (institucionalización procuradores del común por los Reyes Católicos). No se favorece realmente una opción de clase, lo que se está potenciando es una salida personal. A la larga esta será la opción que triunfe. La élite del común acabará comprendiendo definitivamente que la vía revolucionaria no es posible y que la única posibilidad que estaba a su alcance volvía a ser el clientelismo o el establecimiento de lazos familiares con la oligarquía y que por tanto, sólo haciéndose aceptar como miembros de la clase dominante podían mejorar su posición y pasar a las esferas de poder aunque fuera en el más bajo escalón.

El primer rasgo identitario del poder patricio es, por tanto, como queda demostrado, su carácter monopolístico. Esta es, sin duda, la principal característica que lo identifica y singulariza. Pero además, el poder patricio es también privado y patrimonial, la élite burgalesa posee un control absoluto sobre la reproducción interna del mismo y sus esferas de aplicación.

${ }^{13}$ Vid. GUERRERO NAVARRETE, Yolanda (1995): «La política de nombramiento de corregidores en el siglo XV: entre la estrategia regia y la oposición ciudadana». Anales de la Universidad de Alicante, 10, 99-124 y de la misma autora (2003-2004): «Orden público y corregidor en Burgos (siglo XV)». Anales de la Universidad de Alicante, 13, 59-102 


\section{PRIVATIZACIÓN Y PATRIMONIALIZACIÓN: EL CONTROL DEL EJERCICIO Y DE LA REPRODUCCIÓN DEL PODER EN BURGOS}

El clientelismo constituye en la Edad Media el entramado básico de un sistema de relaciones sociales y de poder que es por definición esencialmente privado, doméstico, familiar. También en la ciudad bajomedieval, y con las peculiaridades inherentes a la singularidad urbana, las clientelas pertenecientes a las poderosas familias de las elites locales o los vínculos clientelares que asocian a estas últimas con los «grandes» del reino constituyen una tupida red a través de la cual se articulan necesaria y obligatoriamente el conjunto de las relaciones sociales y las relaciones de poder.

Los vínculos clientelares, junto con la ocupación de cargos en el Regimiento, las relaciones familiares, las actividades económicas, el patrimonio y los niveles de ocio/sociabilidad, constituyen el conjunto de descriptores más habitual utilizado por los medievalistas para significar y diferenciar a las llamadas élites urbanas. Pero el clientelismo no es sólo un signo social identitario de las élites, sino que juega un activo papel político. Forma, sin duda, la telaraña de los partidos y constituye una forma esencial del ejercicio del poder patricio. Un método fácil de demostrar su existencia es la continua legislación municipal y regia en contra de los allegados y de los abusos cometidos por los clientes de los poderosos, frecuente en todas las ciudades de la época. Su erradicación es prácticamente imposible. Para los poderosos, la posesión de clientelas significa, por un lado el mejor instrumento de control sobre ciertos ámbitos a los que su status no les permite acceder directamente, así como el medio a través del cual se significa externamente su dignidad, poder y riqueza. En cierto modo, es el único medio de rentabilizar el poder en términos de tráfico de influencias. Para los inmediatamente inferiores, significa una vía de promoción pública y social que en ocasiones puede llegar a producir pingües beneficios.

Son precisamente estos aspectos del clientelismo, los vinculados directamente con las relaciones y jerarquías establecidas en el ejercicio del poder urbano en el Burgos bajomedieval, los que interesan especialmente en este estudio. Por ello, propongo abordarlos a través de una de sus manifestaciones más visibles: el ejercicio y concesión de oficios subalternos como instrumento de poder para los poderosos y vía de promoción y meritoriaje para los inferiores.

La asociación de hombres pertenecientes a la clientela de los alcaldes y regidores de Burgos a tareas menores ejecutivas de gestión es un hecho perfectamente documentado a lo largo de todo el siglo XV ${ }^{14}$. Es evidente, pues, que los

${ }^{14}$ GUERRERO NAVARRETE, Y. : «Redes clientelares en las estrategias de poder urbanas. Burgos, siglo XV». Comunicación presentada al congreso celebrado en Evora (2009) de la red CIDEHUS (en pubicación) 
oficios menores de carácter ejecutivo constituyen en Burgos un terreno abonado e idóneo para el despliegue de las influencias de los cargos regimentales. Son como hemos afirmado desde el principio el modo en que significa el poder y estatus social de los poderosos a la vez que representan el escenario a través del cual, aspecto sobre el que insistiremos después, los miembros de las elites aspirantes se acercan al poder y se inician en su carrera política mediante una necesaria etapa de «meritoriaje», que los vincula por lazos clientelares a algún miembro de la elite burgalesa y en la cual el aspirante demuestra su eficacia y lealtad al «sistema» al tiempo que se acerca institucionalmente al patriciado ${ }^{15}$. Sin embargo, el clientelismo no es sólo, por un lado, la estrategia preferida de las elites aspirantes en su acceso a la elite de poder, ni, por otro, la forma más clara de representación de estatus social de los poderosos en la Edad Media, sino también un instrumento de proyección del poder de las elites sobre aquellos escenarios que no controlan o no pueden controlar directamente. El caso mejor documentado a este respecto en Burgos es el de los oficios de gestión de la hacienda municipal.

Tradicionalmente, se ha admitido como un hecho que los oficios encargados de la gestión fiscal podían ser considerados como oficios menores, de carácter simplemente ejecutivo, muy alejados de la verdadera toma de decisiones que, como en todos los demás campos del «gobierno» urbano, quedaría reservada a los oficios regimentales. Estaban, pues, reservados a un sector social intermedio, alejado de los cargos de decisión y en muchos casos vinculado por lazos clientelares a los linajes regimentales y en este sentido constituirían un campo más para el despliegue del tráfico de influencias de los poderosos y como vía de promoción para los aspirantes. Sin embargo, mientras que en lo referente a los fieles y arrendadores de rentas (cargos menores) dicha conclusión no ofrece dudas a la luz de las nuevas investigaciones ${ }^{16}$, no ocurre otro tanto con cargos de mayor responsabilidad ejecutiva como el de mayordomo, principal administrador de las rentas ordinarias de Burgos. Efectivamente, a medida que nos adentramos en el siglo XV, los apellidos de los fieles de rentas reales o concejiles dejan de ser significativos desde la perspectiva del análisis de las elites y, sin embargo, encontramos entre los mismos numerosas referencias a oficios como cambiadores, torneros, tanadores, tenderos, freneros,

${ }^{15}$ GUERRERO NAVARRETE, Y. (1984): «Fórmulas de transmisión del poder en el sistema oligárquico burgalés del siglo XV. La ciudad de Burgos». En I Congreso Nacional de historia de Burgos, Junta de Castilla y León, Burgos, 173-183.

${ }^{16}$ GUERRERO NAVARRETE, Y. (2006): «Hacia una prosopografía de los grupos financieros burgaleses». En Y. Guerrero (coord..), Fiscalidad, sociedad y poder en las ciudades castellanas de la Baja Edad Media. Universidad Autónoma de Madrid, Madrid, 203-239. 
cedaceros, carniceros, etc... Ello demostraría que estamos ante un oficio ejecutivo menor dedicado, sin duda, a contentar a las clientelas y a servir a las élites de ámbito para el natural tráfico de influencias. No ocurre así con los mayordomos.

Si analizamos los apellidos y filiación de los mayordomos registrados en la ciudad de Burgos durante el siglo XV, podemos afirmar que en torno a un $50 \%$ de los mismos pueden contarse entre los miembros de la élite de poder de esta ciudad, sobre todo teniendo en cuenta que algunos de ellos repiten y que, por consiguiente, ocupan entre todos más del $50 \%$ de esta centuria. Aún más, los mayordomos que simultanean dicho oficio con cargos de regidor o alcalde, lo hacen con anterioridad al año de promulgación de la llamada sentencia del Conde de Castro que viene a significar en Burgos una especie de pacto entre la élite de poder y la élite de participación en la delimitación de las esferas y ámbitos de poder que les son propios. Eso significa que la propia evolución del sistema de poder en Burgos reserva ciertos «oficios» a las élites intermedias. Vendrían a significar el medio a través del cual estas élites buscan y en algunos casos consiguen una promoción social y política de carácter personal. Sin embargo, los datos demuestran que aquí no se acaba el problema. Mayoritariamente, aquellos mayordomos vinculados con los linajes regimentales ostentan dicho cargo cuando sus respectivos parientes se hayan ya presentes en el regimiento (algunos incluso con más de un miembro). Por tanto, no buscan una plataforma de promoción para sí mismos o para su linaje, como los anteriores, sino que se encuentran ocupando un oficio que puede considerarse como un ámbito más de expresión de las élites de poder, quizás como premio o aprendizaje para algunos de sus miembros más jóvenes. Los datos demuestran, pues, que no es tanto el desinterés de las élites de poder por este oficio, máxime si tenemos en cuenta, que del otro $50 \%$ de los mayordomos burgaleses, un importante porcentaje del mismo queda reservado a elementos no muy alejados de dichas élites: mercaderes, cambistas, en definitiva, grupos financieros vinculados directa o indirectamente a las élites de poder de la ciudad. Los escasos datos obtenidos sobre el patrimonio de algunos de estos mayordomos, demuestran muy a las claras su condición social y su poder económico.

Más significativo aun a este respecto resulta el fracaso del único intento de patrimonialización de este cargo: el de Diego García de Medina, que es mayordomo de Burgos en 1444, 1459, 1460 y 1461. Al margen de otras consideraciones que han sido expuestas en trabajos anteriores (Vid. nota anterior), me inclino a buscar la verdadera razón de este fracaso en la nítida intención de la oligarquía de Burgos por impedir la patrimonialización de este cargo en el seno 
de ningún linaje y su clarísimo interés por seguir conservando el mismo como un campo de expansión de dicha oligarquía. La mayordomía es, pues, en Burgos un oficio donde confluyen tanto los intereses de las elites intermedias como los de las elites de poder. De ahí que se persiga sistemáticamente su permanente y anual disponibilidad y se neutralice con rápida eficacia cualquier intento de patrimonialización.

Si el ejercicio de un poder privado a través de las clientelas y familias constituye una forma de control del ejercicio de poder por parte del patriciado, constituyéndose así en un rasgo identitario del mismo, no lo es menos, su carácter patrimonial, que implica un absoluto control sobre la producción y reproducción del poder en el seno del sistema. En el conjunto de dicho sistema, la clave principal radica en cómo se llega a «ser», a «pertenecer» a dicho patriciado y, sobre todo, qué tipo de estrategias despliega la propia élite para intentar controlar los mecanismos internos de su reproducción.

Toda una serie de indicios apuntan a priori el exhaustivo control que la elite de poder burgalesa ejercía sobre los mecanismos de producción y reproducción del poder en el seno de la misma. En primer lugar, la escasa o nula incidencia de las cartas expectativas o de acrecentamiento de oficios ciudadanos, que ya he analizado en otra ocasión ${ }^{17}$. En segundo lugar, es un hecho demostrado que, como mencionaba antes, en Burgos el patriciado había logrado perfeccionar una especie de protocolo de ascenso, una cierta "carrera política», que debían completar todos aquellos aspirantes a un oficio regimental y, por consiguiente, a ser reconocidos como miembros indiscutibles de la élite. A mi entender, la pertenencia por derecho al círculo oligárquico suponía no tanto el ejercicio de un poder real y efectivo -que también-, como el reconocimiento público de una determinada categoría social. Así el acceso a un cargo regimental puede ser considerado como la etapa final de un proceso ennoblecedor que arranca de la creación de una plataforma económica patrimonial de cierta altura. El hecho de que muchos, a pesar de poseer importantes bienes de fortuna, quedaran estancados en las etapas intermedias, demuestra, primero, hasta qué punto era difícil culminar este proceso de dignificación social y, segundo, que el patrimonio era una condición indispensable pero

\footnotetext{
${ }^{17}$ Y. Guerrero Navarrete, «Del concejo medieval a la ciudad moderna. El papel de las cartas expectativa de oficios ciudadanos en la transformación de los municipios castellanos. El caso de Burgos y Cuenca». En La Península Ibérica en la era de los descubrimientos 1391-1492. Sevilla, 1991, pp. 1013-1025. A este respecto, por ejemplo es muy significativo el caso de la carta expectativa que Enrique IV otorgo a favor del comendador Fernando de Amorós a quien la ciudad se negó en todo momento a admitir aun a costa de incurrir en las penas impuestas en los casos de desobediencia de mandatos regios (Ibid. 1017 y 1018).
} 
no vinculante. La construcción de un sólido patrimonio familiar constituiría la plataforma de arranque que permitiría a posteriori el reconocimiento de los miembros de ese linaje de la condición de «hombres buenos», es decir poseedores de una probidad reconocida, que son justos y gozan de buena fama. Son la elite del común, aquellos que están en condiciones de abordar la segunda de las etapas: el acercamiento a la clase dominante mediante el establecimiento de redes de carácter matrimonial o clientelar y la colaboración en las tareas de gobierno, bien a través de la titularidad de oficios menores de carácter ejecutivo, bien mediante su presencia en actos de cierta relevancia ciudadana. Se trataría de una etapa de aprendizaje, de prueba y, sobre todo, de búsqueda de alianzas consolidadas entre los que más tarde o más temprano habrán de decidir la suerte que ha de correr cualquier solicitud de entrada en el regimiento de la ciudad.

Esta solicitud de ingreso en el regimiento constituía la etapa final y, sin duda, la de más difícil consecución de las hasta ahora expuestas. La carta por la que el rey nombraba a un nuevo regidor o alcalde adoptaba generalmente la forma de una renuncia directa del cargo por su anterior titular o de una carta expectativa de un oficio vacante, pero escondía corrientemente una transacción que en la mayoría de los casos se hacía en base a una fuerte suma de dinero. De ahí una de las cláusulas novedosas introducidas en las renuncias de oficios en época de los Reyes Católicos. Sin embargo, ello no garantizaba en Burgos su automática aceptación. En numerosos casos el regimiento de Burgos optaba por «obedesçerla como a carta de nuestro señor rey e natural» pero reservarse su cumplimiento.

La documentación que poseemos en torno al recibimiento de nuevos cargos regimentales demuestra que en Burgos la aceptación al cargo solo se realizaba sin ningún problema cuando se trataba de renuncias directas de padres a hijos; en el resto de los casos era rechazada totalmente de forma mayoritaria, y únicamente en casos excepcionales, admitida tras muchas dificultades. ${ }^{18}$. Es por ello y este es el tercero de los indicios que demuestran el absoluto control que ejerce la elite burgalesa sobre la pertenencia o exclusión del patriciado, que, a pesar de la existencia de métodos «no usuales» que permiten a ciertos y escogidos miembros de la elite económica de Burgos romper el círculo estricto del patriciado, el método más habitual y «fácil» para ello fue, en el Burgos del siglo XV, la renuncia de cargos regimentales por vía de linaje.

En Burgos, como ya apuntamos antes al mencionar la escasa efectividad de las cartas expectativas de oficios regimentales en la ciudad de Burgos, la renun-

${ }^{18}$ A.M.B., LL.AA., 1431/2/3, fol. 49r. 
cia personal del titular del oficio fue prácticamente la única forma de acceso a los cargos regimentales, alcaldías y regidurías. La progresiva ritualización del procedimiento, observable en su evolución a lo largo del siglo XV, habla a favor de su institucionalización y consolidación. Si en los años iniciales se describe con cierta prolijidad la ceremonia, a finales del periodo, ya en época de los reyes católicos esta está ya muy ritualizada y es similar a la de otros oficios ciudadanos. A finales del periodo estudiado, ya en los primeros años del XVI, la documentación burgalesa iguala el procedimiento en todas las renuncias, ya se trate de renuncias entre parientes directos o entre extraños familiarmente hablando ${ }^{19}$. La aceptación de las mismas, en un caso u otro, es tan habitual y automática que ya ni se incorpora al acta de la sesión de recibimiento la merced regia de facultad de renuncia del oficio y en muchas ocasiones ni se incluye el juramento del nuevo oficial (salvo en los aspectos mencionados de venalidad y acrecentamiento). Parece ser que la Corona y las mismas autoridades urbanas han asumido las ventajas que para ambos suponía el sistema de renuncias: la necesaria aceptación y permisividad por parte del monarca que reforzaba, al menos teóricamente en última instancia, la intervención y control regio, y el respeto a la voluntad e intereses privados y de linaje de los patriciados urbanos.

Parece pues evidente que el patriciado burgalés ha venido perfeccionando e institucionalizando un sistema de reproducción del poder que garantiza el absoluto control del acceso a los oficios regimentales a los miembros de esta elite. Bien sea por métodos no usuales, bien sea mediante la facultad de asociar y renunciar al cargo en el seno de un mismo linaje, el sistema no posee apenas fisuras: poco importa que algunos linajes se vean sustituidos por otros o que asciendan necesariamente otros nuevos, siempre y cuando sean estos mismos patricios los que deciden quien o quienes deben «ser»o «pertenecer» a la élite y, por consiguiente, gozar de sus privilegios.

Poder monopolístico, reforzado a través del uso interno y externo de las clientelas, poder privado, por tanto, que se ejerce en el seno de las familias y clientelas, y patrimonial a fin de garantizar el control de la producción y reproducción en el seno del mismo. El último de los rasgos identitarios del poder urbano en Burgos es la cristalización de una conciencia oligárquica y su traducción al conjunto de la sociedad a través de un sistema complejo de actitudes, lenguajes y símbolos que reproducen, a su vez, la percepción social de dicho poder patricio.

${ }^{19}$ GUERRERO NAVARRETE, Y.» «Ser»y «Pertenecer» a la elite: estrategias de reproducción del poder en el Burgos bajomedieval» (en publicación). 


\section{LA CRISTALIZACIÓN DE UNA CONCIENCIA OLIGÁRQUICA Y SU «EXTERNALIZACION»: LA PERCEPCIÓN DEL PODER PATRICIO EN BURGOS}

En la Edad Media el poder no se sentía, ni se imaginaba habitualmente, como un ejercicio de gobierno. El poder se materializaba y percibía en la sumisión, las alianzas, la paternidad, la amistad o las ceremonias y, también, en las súplicas, los juramentos, las prestaciones de testimonio y, sobre todo, en la presencia del señor, al que se rendía homenaje. Así, las formas en que los ciudadanos experimentaban el poder -o los modos en que lo ejercían, imaginaban, festejaban o respondían a él- atestiguan una específica cultura del poder, con características propias y peculiares en sus facetas de expresión, justificación y expectativa del mismo, y una particular identidad política a ella asociada.

En Burgos, como hemos visto, los siglos bajomedievales han ido consolidando un sistema de poder que se percibe como íntimamente asociado a una élite de poder, que, a pesar de su singularidad, no es muy diferente a la de otras ciudades castellanas y europeas, a las que ya hace tiempo, y a pesar de la heterogeneidad que las caracteriza, definí en sus principales rasgos identitarios ${ }^{20}$ : en primer lugar, riqueza. Altos niveles de fortuna personal y familiar eran condición necesaria, aunque no suficiente, para pertenecer a este grupo. Que esa fortuna, aun con sus diferencias cuantitativas, procediese de los negocios mercantiles, de la especulación inmobiliaria o de los cargos cortesanos, es hasta cierto punto secundario. En segundo lugar, ocupan espacios políticos y posiciones intermedias, aunque quizá no equidistantes, entre la nobleza y el común urbano, siempre con unos márgenes fluctuantes hacia arriba y hacia abajo. Mientras la nobleza feudal tenía un radio de acción regional o supraregional, el radio genuino de influencia de la oligarquía urbana coincidía con el de la jurisdicción concejil, es decir la ciudad o villa y su tierra y, como mucho, algunos otros espacios comarcanos. Este es, junto con la riqueza, el otro gran fundamento del poder patricio: el poder municipal. En tercer lugar, el patriciado urbano se diferencia del resto de sus convecinos por compartir un modo de vida y una mentalidad específica, distintiva de su condición de clase dominante. Y en la lógica del sistema feudal al que pertenece enteramente la ciudad bajomedieval, dicha forma de vida y mentalidad pretende reproducir la de la clase feudal dominante. No es, por tanto, burguesa, sino profundamente aristocrática: la aspiración a la hidalguía, constante de todas las elites urbanas castellanas, una estrategia política, social y económica que persigue insistentemente el modo de vida noble, la búsqueda en

${ }^{20}$ GUERRERO NAVARRTE, Yolanda (1998): «Elites urbanas en el siglo XV: Burgos y Cuenca. Revista D' historia medieval. Universidad de Valencia, 9, 81-104. 
la cercanía del monarca o de su entorno más inmediato el continuo reconocimiento de nuevos honores: cargos o quitaciones de corte, acostamientos, oficios honoríficos; la opción consciente de una forma de vida conforme al ideal de vida noble: de las rentas de la tierra, de las alcabalas, tercias y diezmos. El ideal caballeresco forma parte esencial de su cultura. El modelo aristocrático se aprecia también en el carácter suntuario y lujoso de muchos de los bienes muebles, las formas de disfrute del ocio, el vestido, el gusto por el mecenazgo artístico, la dotación de iglesias y capellanías. Dichas aspiraciones se traducen muy pronto en todo un conjunto de formas de estructurarse internamente, de relacionarse entre sí y de cara al poder que, aun con variantes morfológicas, les proporcionan una identidad como grupo social, además de facilitar su intervención política. Al igual que en el caso nobiliario dichas redes de sociabilidad internas estuvieron basadas en el establecimiento de vínculos familiares, de parentesco por vía matrimonial y clientelares.

En definitiva rasgos que singularizan a estos patricios, pero que también sirven para identificarlos y significarlos como grupo social y político. Rasgos que, en resumen, distinguen al conjunto de individuos y linajes que por su riqueza y poder, por su prestigio, por su influencia, son miembros indiscutibles de esa élite socio-política que la ciudad de Soest definía, retomando la cita inicial de este trabajo, ya en la segunda mitad del siglo XII con las siguientes palabras: «los mejores de la ciudad, por cuya autoridad la ciudad prospera y en los que se basa la esencia del derecho y de la fortuna». Es un hecho que a finales de la Edad Media las autoridades urbanas buscan persistentemente una ciudad más bella y más apacible a la convivencia, pero, sobre todo más insigne, más honorable. «Ornato» $\mathrm{y}$ «honra» son los dos atributos a los que constantemente hacen referencia alcaldes y regidores en Burgos. Como ha afirmado J.A. Bonachía «dos ideales que responden a la construcción lenta, pausada, pero incesante de una imagen de Burgos, la que ellos tienen de su ciudad y la que quieren ofrecer a los demás: la imagen de una ciudad noble, que se cimenta sobre el sistema de valores caballeresco que propugnan los grupos dominantes urbanos a semejanza de la aristocracia del reino» ${ }^{21}$. La voluntad de ennoblecimiento característica del patriciado burgalés termina impregnando a la misma ciudad, en donde viven y a la que, como gobernantes, representan frente al exterior, "contribuyendo a su ornato -en un mundo en que el aspecto externo y las apariencias establecen códigos de valor-, defendiendo y promoviendo su honra, ennoblecen su ciudad y se ennoblecen a sí mismos, a quienes la dirigen y dominan» ${ }^{22}$.

${ }^{21}$ J.A. Bonachía Hernando, «La ciudad de Burgos en la época del consulado». Actas del V Centenario del consulado de Burgos, I. Burgos, 1994, pp. 140.

22 Ibid. Pp. 140. 
Una cuidada política de caridad y limosnas promovida desde el poder patricio $^{23}$, el cuidado por el urbanismo, la limpieza, el ornato de sus calles y edificios, preocupaciones que ocupan un lugar destacado en el conjunto de las ordenanzas municipales que dicta el patriciado burgalés a lo largo del siglo XV ${ }^{24}$, a los que se añade a finales del cuatrocientos el cuidado por la memoria histórica de la ciudad, el archivo y custodia de sus documentos y recuerdos, la construcción de un edificio adecuado y específico para albergar el poder urbano (la casa de los ayuntamientos) ${ }^{25}$, son, sin duda, algunos de los vehículos preferentes de externalización» de dicho poder patricio.

De cara a sus conciudadanos, se acuña, además, un especial lenguaje político, que conocemos preferentemente a través de los discursos realizados por miembros de la elite en casos especialmente sensibles, generalmente fiscalidad extraordinaria o cuestiones vinculadas al orden público, en donde constantemente se apela a conceptos como servicio a la respublica, pro e bien común, «onra». Buen ejemplo del mismo es el siguiente párrafo extraído del inicio de las ordenanzas de justicia publicadas en Burgos el año 1411: «..........por ende los alcaldes, merino et rregidores de la muy noble çibdad de Burgos, cabeça de Castilla et camara del rey nuestro señor, consyderando quantos males e daños se podrian recresçer non guardandose nin conpliendose bien la dicha justiçia et seruiçio del rey nuestro señor nin fesiendose bien el regimiento en la dicha çibdad et quanta verguença desto nos podrian recresçer e quanta perdida et mal, e acatando la grand fiança que el rey nuestro señor de nosotros fase en nos encomendar la justiçia et regimiento della e quantos buenos e prosperidades pueden recresçerse a la dicha çibdad e a los que en ella biven a que nosotros somos obligados a dar cuenta, et quanta onrra et pro e buena fama a nosotros se sygue por faser bien asy la dicha justiçia como el buen regimiento en la dicha çibdad e su tierra, por ende todos aviendo voluntad de bien bevir e guardar seruiçio del rey nuestro señor e la su justiçia et el buen regimiento de la dicha çibdad que demos buena cuenta della e de nos a Nuestro Señor Dios et al dicho señor rey e la justiçia sea esforçada e preualesca e el regimiento de la dicha çibdad sea mejor fecho et guardado, fasemos esta ordenança que se sygue» ${ }^{26}$.

${ }^{23}$ LÓPEZ PÉREZ, M. A., REDONDO JARILLO, C. (2006): «Gastos de representación en Burgos: limosnas, regalos y honras fúnebres. Libros de Actas Municipales.1379-1476». En Y. Guerrero Navarrete (coord..), Fiscalidad, sociedad y poder en las ciudades castellanas de la Baja Edad Media. Madrid, Universidad Autónoma de Madrid, 151-202.

${ }^{24}$ GUERRERO NAVARRETE, Y. (1987): «La estructura urbana de Burgos en el siglo XV». En Homenaje al profesor Torres Fontes Murcia. Universidad de Murcia, 737-750.

25 A.M.B., LL.AA. 1502.

${ }^{26}$ Archivo Municipal de Burgos (en adelante A.M.B.), Libros de Actas (en adelante LL.AA.) 1411, fols. 41r y v. Publi. J.A. Bonachia Hernando, El concejo de Burgos en la Baja Edad Media (1345-1426).. Valladolid, 1978, pp. 164 y 165. 
Su poder es percibido por sus conciudadanos a través de la reconocida probidad que les proporciona su pertenencia a la élite y se materializa en el solemne ceremonial asociado a sus cargos ${ }^{27}$, la riqueza y preeminencia que manifiestan y que disfrutan en todos los actos púbicos, incluidas las solemnes procesiones y festejos urbanos, y, sobre todo, en la amplitud de sus inquietas clientelas que acostumbran a sembrar de inconvenientes la paz de la ciudad y el orden público. Pero, el poder patricio no debe percibirse y sentirse sólo en el interior el recinto urbano, debe proyectarse con fuerza hacia el conjunto de vasallos que, alejados en su vivir diario del recinto amurallado, son el símbolo externo más importante del poderío y preeminencia de Burgos y su elite en el conjunto del reino.

Burgos posee, por razones vinculadas a su desarrollo económico y político ${ }^{28}$, un señorío disperso objeto constante de las ambiciones de la nobleza del entorno y sobre el que la ciudad y su elite desarrolla una estrategia extremadamente celosa por salvaguardar todos los signos y símbolos de reconocimiento externo del ejercicio de su señorío y jurisdicción. Baste, a modo de ejemplo, lo recogido en el siglo XVI por el siguiente documento con referencia a las rentas, ofiçios y derechos que Burgos tenía en Miranda y Pancorbo 29: "Lo que Burgos tiene en Miranda y Pancorbo, y de ello posesión inmemorial... Llámanse vasallos de la çibdat en todos los escriptos y capitulaciones y ordenanças... Si quieren hazer ordenanças o empeñar propios, piden a la çibdat lizençia y confirmaçion... En Pancorbo nombra el conzejo dos obres alcaldes ordinarios por un año...y Bienense a confirmar a Burgos; y lo mismo hacen otros

${ }^{27}$ E luego el señor Garçia de Cotes tomo la dicha carta en su mano e asy tomada la veso e puso sobre su cabeza e por sy e en nonbre de los dichos señores dixeron que obedecían e obedecieron la dicha carta de sus altesas con la mayor reberençia e obediencia que podian e devian como carta e mandado de sus reyes e señores naturales que dios dexe bevir e reynar por muchos tiempos buenos, e quanto al cumplimiento de ella que ellos estavan prestos de la cumplir e cunplian en todo e por todo e segund que en ella se contenia, e en cumpliéndola recibieron del dicho Diego de Soria la solemnidad e juramento que en tal caso se requiere.E luego los dichos señores pusieron en la tenençia e posesion del dicho ofiçio de regimiento en lugar del dicho su aguelo e en lugar de (borrado) lo pusieron en la sylla o lugar que es debaxo de la sylla e lugar de Antonio de Santander regidor, e asy el dicho Diego de Soria se tomo e aprehendio la dicha posesion vel casy çebil e natural, e asy tomada la dicha posesion fue por todos avido e tenido por regidor de esta çibdad. Los dichos señores para faser por conçejo el dicho recibimiento mandaron llamar a conçejo. (Recibimiento de Diego de Soria. AM.B., LL.AA., 1502, fols. 46v-48r).

${ }^{28}$ GUERRERO NAVARRETE, Y. (1989): «Aproximación a las relaciones campo-ciudad en la edad Media: el alfoz y el señorio burgales. Génesis y primer desarrollo». Historia. Instituciones y Documentos, Universidad de Sevilla, 16, 15-45.

${ }^{29}$ A.G.S. Diversos de Castilla, Leg. 40, fol. 37. 
ofiçiales del conçejo...... las apelaçiones çeviles y criminales dellos vienen a Burgos, conocen de ellos dos alcaldes de vasallos que la çibdat nonbra cada año..... Biene en Miranda otro tanto como lo arriba contenido....».

Burgos es el «señor» de las villas de Pancorbo, Miranda de Ebro, Muñó, Lara y Barbadillo del Mercado. En ellas la única horca, es la de la ciudad. Sus alcaldes lo son por especial reconocimiento de Burgos y juzgan sólo en primera instancia, las apelaciones deben llegar a los «alcaldes de los vasallos» nombrados anualmente por la ciudad. Justicia, rentas y derechos de carácter jurisdiccional ${ }^{30}$, control absoluto sobre los gobiernos locales y monopolio de mercado urbano, son, sin duda, los rasgos más evidentes del ejercicio del poder señorial. Un poder señorial que no siempre es bien percibido y aceptado por sus vasallos, pero que, al igual que en el caso de los conciudadanos, disfruta de un lenguaje propio y de un ceremonial específico, donde se refuerzan sistemáticamente aquellos giros y expresiones que hacen referencia a la sumisión, lealtad y obediencia debidas. Algunos ejemplos: es frecuente que las cartas enviadas a las villas de señorío, vayan encabezadas como fórmulas y expresiones como «nos el conçejo de Burgos... enviamos saludar a vos el conçejo de las nuestras villas de Maçuela e Pampliega y nuestros vasallos» ${ }^{31}$, en el transcurso de las mismas se hace referencia frecuentemente a los "señores de la çibdad» a los «señores regidores» ${ }^{32}$, algunos de los cuales poseen, además, derechos específicos en dichas villas (yantar, acogida o derechos de vendimia) (Vid. nota 30); por último, las desobediencias e intentos de insumisión de villas o particulares provocan caer e incurrir en «nota de ynfame e trayçion» ${ }^{33}$. También los actos formales por los que se presta al señor urbano pleito homenaje a la recepción o entrega de una fortaleza perteneciente a una villa de señorío, constituyen un signo evidente de percepción del poder señorial y de «externalización» del poder urbano.

Pero, por encima de todo, el poder patricio debe traducirse externamente como referente frente a los otros poderes. La alteridad es, a la postre, la que consolida todo proyecto de identidad política. Eso significa definirse y singularizarse a uno mismo frente a otras ciudades, la nobleza -laica o eclesiástica, cercana o alejada- y, por supuesto, la Corona.

\footnotetext{
30 GUERRERO NAVARRETE, Y. (1985): Organización y Gobierno en Burgos durante el reinado de Enrique IV de Castilla (1453-1476).Madrid, pp.55-61.

${ }^{31}$ AMb. S.H., no 3610 (bis).

32 Ibid. No 4034.

${ }^{33}$ Ibid. 4071.
} 
Hace ya algunos años que medievalistas y modernistas europeos como M. Boone y P. Stabel ${ }^{34}$, Martha C. Howell ${ }^{35}$, B. Schneidmuller ${ }^{36}$, P. J. Goldberg ${ }^{37}$, M. Booney ${ }^{38}$ o G. Rooser ${ }^{39}$, modernistas españoles como J.I Fortea Pérez ${ }^{40} \mathrm{O}$ J. Amelang ${ }^{41}$ y en menor medida, medievalistas hispanos como J.A. Bonachia Hernando ${ }^{42}$, por citar sólo a algunos de los más representativos, han comenzado a focalizar el interés de la historia urbana, entre otras cosas, sobre la reconstrucción de la memoria urbana, los ideales de ciudad y el discurso urbano. La ciudad «tenía y reclamaba sus títulos de nobleza, hacía demostración de símbolos y atributos externos reservados en principio a este estamento, y se llamaba y se hacía llamar con apelativos nobiliarios, sin renunciar en ningún momento a este otro carácter de Civitas Dei, de pequeño reino de Dios en la tierra.... Ser ciudad en el reino castellano enaltecía la honra, aportaba lustre, además de otras mercedes, franquicias, libertades.... En ello no jugaba un papel fundamental la cantidad de población, sino que contaba el rango, los triunfos y contribuciones, los personajes dignos de memoria, su aportación al cuerpo del Rey y el reino» ${ }^{43}$.

Hace poco ${ }^{44}$ he tratado aspectos relacionados con este tema al analizar la iniciativa que Burgos adopta en agosto de 1391 al enviar al rey, a la reina, a

${ }^{34}$ BOONE, M.; STABEL, P, (2000): Shaping the urban identity. In late medieval Europe. Brussels

${ }^{35}$ HOWELL, M.C. (2000): «The spaces of the late medieval urbanity». En M. Boone and P. Stabel, Shaping the urban... 3-23.

${ }^{36}$ SCHNEIDMULLER, B. (2000): «Constructing the past by jeans of the present. Historiographical foundations of medieval institutions, dynasties, peopels \& comunities». En G. Althoff, J. Fried \& P.J. Geary (eds.), Medieval concepts of the past. Ritual, memory, Historiography. Cambridge, 167-192.

37 GOLDBERG, J. P. (1990): «Urban identity and the poll taxes of 1377, 1379 and 1381». Economic history review, 43:2, 194-216.

${ }^{38}$ BONNEY, M. (1990): Lordhsip and the urban community. Durham and its overlords, 1250 1540. Cambridge.

${ }^{39}$ ROOSER, G. (1996): «Myth, image and social process in the english medieval town». Urban Hisotry, 23:1, 5.25.

${ }^{40}$ FORTEA PÉREZ, J. I. (ed) (1997): Imágenes de la diversidad. El mundo urbano en la Corona de Castilla (siglos XVI- XVIII). Cantabria.

${ }^{41}$ AMELANG, J. (1997): «Las formas del discurso urbano». En J.I. Fortea Pérez, Imágenes de la diversidad..., 189-197.

42 BONACHIA HERNNADO, J.I. (1996): «Mas honrada que ciudad de mis reinos..... La Nobleza y el Honor en el imaginario urbano (Burgos en la Baja Edad Media)». En J.A. Bonachía Hernando (coord.), La ciudad medieval. Valladolid, 169-212.

${ }^{43}$ LÓPEZ PÉREZ, M. A. (2005/2006): Identidad urbana e idea de ciudad en el mundo hispano (siglos XV-XVI): estado de la cuestión. Trabajo de investigación para la obtención del D.E.A., presentado en el curso 2005/2006 en el Dpto. de $\mathrm{H}^{\mathrm{a}}$ Medieval de la UAM, bajo la dirección de la Dra. Yolanda Guerrero Navarrete (inédito).pp. 47 y 488.

${ }^{44}$ GUERRERO NAVARRETE, Y. (2009): «Identidad y «honor» urbano: Cortes en Burgos, 1391-1392». En Castilla y el mundo feudal. Homenaje al profesor Julio Valdeón. Valladolid. Junta bde Castilla y León I, 551-565. 
los miembros del Consejo, al duque de Benavente, al arzobispo de Toledo y al maestre de Alcántara una carta de creencia «sobre rason de la discordia que es entre vosotros e los otros señores que estan en el consejo de nuestro señor el rey ${ }^{45}$. La decisión de Burgos se encuadra en el intento -exitoso por cierto- de solucionar una ya larga crisis provocada por el enfrentamiento entre dos sectores de la nobleza castellana, liderados uno por el duque de Benavente y los señores arriba citados, y por el arzobispo de Santiago otro, a raíz de la repentina muerte del monarca Juan I y la todavía minoridad de su legítimo heredero Enrique III, en el marco de un proceso todavía inmaduro de consolidación institucional del reino castellano tras la aun no muy lejana entronización de los Trastámara. Burgos, en su condición de «cabeza de Castilla e Camara del rey nuestro señor», decide mediar en dicho conflicto, proponiendo la celebración en dicha ciudad de unas Cortes, «porque, segunt que se fallara por las coronicas antiquas, las cosas que aqui se firmasen fuesen de mayor atoridad e fuesen perpetuas, e se fallara que to que se fase en esta çibdat en los tienpos de los otros reyes syenpre se guardo e se touo e fiamos en que se fara de aqui adelant» ${ }^{46}$. Al reforzamiento del papel de las Cortes y, dentro de ellas, a la preeminencia de la ciudad de Burgos, hacen referencia las constantes alusiones al «honor» urbano, la «honra y la verdad» de la ciudad. Los términos en que tanto el conde de Benavente como el arzobispo de Toledo agradecen a la ciudad sus esfuerzos no dejan lugar a dudas «e otrosi segunt cunple a onrra e estado desa çibdad e de todos vosotros» ${ }^{47}$, así como las palabras que han de jurar para garantizar la paz durante la celebración de las Cortes todos los vecinos de la ciudad, clérigos y laicos, cristianos, moros y judíos, empezando por el obispo: «de se quitar e amar e ser juntos para guardar la onrra de la dicha çibdat» ${ }^{48}$

Como han puesto de manifiesto recientes estudios el estatus de una ciudad en época preindustrial es de carácter más cualitativo que cuantitativo. No está vinculado a su número de habitantes o a su actividad económica, sino a la «honorabilidad» de sus habitantes, vivos o muertos, a sus monumentos y edificios, y a los acontecimientos relevantes para el «Cuerpo Político» de la monarquía que han tenido lugar en el espacio urbano. La ciudad medieval y moderna es,

${ }^{45}$ Archivo Municipal de Burgos, Libros de Actas (A.M.B., LL.AA.), 1391, fols. 1r-2r. Esas cartas y otras que recogen documentación conservada en el Archivo Municipal de Burgos al respecto fueron publicadas en su día por A. Salva, Las Cortes de Burgos de 1392. Burgos, 1891

${ }^{46}$ AMB, LL.AA., 1391, fols. 2v.

${ }^{47}$ AMB., LL.AA., 1391, fols. 4r. Otra idéntica se recibe firmada por el arzobispo de Toledo (4 ryv). También el rey agradece mediante una carta los servicios prestados en este asunto por Burgos (fols. 3v y 4r).

${ }^{48}$ A.M.B., LL.AA., 1391, fol.. 9 ryv (Vid. Apéndice no 3). 
según esto, no solo una agrupación económica y productiva de sus habitantes, sino sobre todo una agrupación política, una unión que presenta una imagen de sí misma, un centro de poder, poseedor de un imaginario propio, que la singulariza con respecto a las demás y al conjunto de los poderes que conviven y comparten escenario dentro de la Monarquía Castellana ${ }^{49}$.

En este sentido, el análisis de las relaciones con otros poderes alcanza un valor imprescindible. El camino hacia la monarquía hispánica es un camino de consensos y conflictos entre diferentes poderes, cada uno de los cuales busca y persigue su identidad y ámbito propios en el marco del reconocimiento de la superioridad de poder monárquico y en el seno de un proceso dual de singularización: por sí mismos y por oposición al resto. La historiografía medieval castellana ha centrado el análisis de este proceso hasta el momento mucho más en el tema monarquía/ciudades y en menor medida en el de la relación con la nobleza y, cuando se ha ocupado de este último, lo ha hecho de forma unilateral, focalizando exclusivamente el problema sobre el carácter «depredador» de la aristocracia bajomedieval hacia el territorio y los privilegios urbanos ${ }^{50}$. Sin embargo, desde la perspectiva de esa «nueva mirada» el sistema de relaciones que vinculan a las ciudades con la nobleza castellana se presenta como mucho más variado y complejo, salpicado de consensos y conflictos. Este es, todavía hoy más un proyecto que una realidad.

En la Baja Edad Media un número importante de ciudades castellanas han sucumbido, con la inestimable colaboración de la Corona, a la presión de la jurisdicción señorial, mientras que otras -las menos- conservan su condición de realengo. Incluso en estas últimas -las que verdaderamente me interesan- la presencia de miembros de la más alta nobleza del reino castellano es un hecho hoy por hoy indiscutido. En algunos casos dicha presencia no se limita a una simple residencia urbana, sino que la influencia y poder nobiliarios penetran e influyen poderosamente todo el tejido social y político de la ciudad; en otros (los menos)

\footnotetext{
${ }^{49}$ Marcos Martín, Alberto (1992): «Qué es una ciudad en la época moderna?. Reflexión histórica sobre el fenómeno de lo urbano». De esclavos a señores. Valladolid, 137-154. También, del mismo autor, (1997): «Percepciones materiales del imaginario urbano en la España moderna». En J.I. Fortea Pérez (ed.), Imágenes de la diversidad. El mundo urbano en la Corona de Castilla (siglos XVI- XVIII). Cantabria. Cit. M.A. López Pérez, Identidad urbana e idea de ciudad en el mundo hispano (siglos XV-XVI): estado de la cuestión. Trabajo de investigación para la obtención del D.E.A., presentado en el curso 2005/2006 en el Dpto. de $\mathrm{H}^{\mathrm{a}}$ Medieval de la UAM, bajo la dirección de la Dra. Yolanda Guerrero Navarrete (inédito), pp 4 y 9.

${ }^{50}$ Un último trabajo en este sentido que plantea ya alternativas a esta visión tradicional es el de M. ASENJO (2006), «La aristocratización política en Castilla y el proceso de participación urbana(1252-1520)». En J.M. Nieto Soria, La Monarquía como conflicto en la Corona castellano-leonesa. Madrid, 133-196.
} 
estamos ante «vecinos» excepcionales a quienes sin lugar a dudas se acude y se respeta, pero que, salvo ocasiones excepcionales, carecen de poder institucional efectivo en el sistema urbano. Burgos, como es sabido, pertenece a estas últimas. Por ello, el análisis de las relaciones entre las elites urbanas y nobiliarias adquiere en el contexto del sistema urbano burgalés un interés especial o mayor del que poseen otros concejos más intensamente mediatizados por la nobleza o, en definitiva más «nobilizados».

Burgos, su señorío y alfoz, poseen en el siglo XV -como el resto de las ciudades castellanas- poderosos vecinos tanto laicos como eclesiásticos. Entre estos últimos destacan en este período los monasterios de las Huelgas y el de San Pedro de Cardeña. Entre los primeros, hay que mencionar indudablemente en lugar destacado a los Velasco, condes de Haro y futuros duques de Frías, y a los Estúniga, condes de Plasencia y alcaides de la fortaleza de Burgos, pero también a los Rojas, Sarmiento, Salinas, Castro, linajes de rango intermedio, pero capaces de desarrollar una cierta, y a veces molesta, influencia en el espacio territorial bajo jurisdicción de la ciudad. Junto a estos poderosos vecinos, y dada la preeminencia que ha alcanzado en este época dentro del estamento ciudadano, Burgos debe resolver en multitud de ocasiones situaciones de colaboración y conflicto planteadas por o con miembros de las elites nobiliarias del reino alejadas de su entorno e influencia territorial. Un buen ejemplo de ello son los acontecimientos que relataba al comienzo de esta exposición.

El análisis de la documentación burgalesa del período me ha permitido esbozar el siguiente esquema clasificatorio de las diferentes y complejas situaciones que reflejan las relaciones establecidas por la elite urbana y la nobleza castellana en el siglo XV y que viene a constituir un primer esquema de mi futura investigación: en primer lugar, habitualmente, y en consonancia con la ya tradicional «avidez» que caracteriza a la nobleza europea bajomedieval, los nobles se muestran también en el espacio burgalés como verdaderos «depredadores» de la tierra y de la jurisdicción de la ciudad. Este es, probablemente por su extrema conflictividad y por la importancia que le conceden las mismas ciudades, el tipo de relación que mayores restos documentales ha dejado y, por consiguiente, la mejor estudiada y más destacada por el conjunto de la historiografía peninsular. En segundo lugar, un tipo de relación muy habitual en la documentación e igualmente ubicada en el marco del conflicto es aquella que se traduce en pleitos y pequeñas disputas que implican diferencias por cuestiones de jurisdicción, vasallos o términos. Magnificada a mi entender su importancia por su masiva presencia en nuestras fuentes -fundamentalmente de carácter jurídico-, constituyen conflictos de menor importancia, simples roces entre vecinos, en muchos casos sin importancia real para el tema que realmente nos interesa. En 
tercer lugar, también con cierta frecuencia, y mayor en el caso de Burgos por su preeminencia en el conjunto de las ciudades castellanas, nobleza y elites urbanas comparten situaciones de conflicto y colaboración en el transcurso de los acontecimientos que salpican el proceso de construcción de la Monarquía Peninsular. La implicación de la ciudad y sus élites en la política general del reino la lleva al establecimiento de alianzas a favor o en contra del resto de las elites de poder del reino (nobleza laica o eclesiástica, monarca u otras ciudades). Aquí nos situamos ya en un terreno mucho más complejo. Por un lado, la ciudad y sus élites buscan institucionalmente de forma consciente reforzar su singularidad e identidad en el conjunto de la sociedad política castellana de la época. Por otro, es un hecho conocido que la casi totalidad de las élites urbanas se hallan en esta época integradas en las redes clientelares de la alta y media nobleza y, como tales, obligadas a seguir y apoyar a sus tácitos «señores». Por último, y muy vinculada al anterior aspecto, he de mencionar la presencia también habitual en la documentación del período de un tipo de relación nobleza-elites urbanas, no ya de conflicto sino de colaboración, que en un intercambio absolutamente bilateral de favores permite a la nobleza extender su ámbito de influencias a la ciudad y a ésta, y mucho más concretamente a sus élites, beneficiarse directamente de las influencias que solo un noble es capaz de desplegar.

En general podríamos afirmar que todas ellas pueden inscribirse bien en una situación de conflicto o, por el contrario, de alianza y cooperación. La primera de estas situaciones -la de conflicto- ha sido, sin duda la más estudiada. No voy a insistir de nuevo en ella ${ }^{51}$. Sólo cabe concluir lo que ya expuse hace tiempo: es un hecho probado que la conservación del señorío burgalés constituye una fuente considerable de gastos para la ciudad; por otro lado, las rentas provenientes del ejercicio del poder señorial generalmente no se cobran y, cuando lo hacen, es tarde o mal. No es, por tanto, un interés fundamentalmente económico el que mueve a la ciudad a neutralizar con todas sus fuerzas las acciones nobiliarias en ese sentido, salvo en ocasiones concretas donde una determinada villa es vital para el comercio o los intereses económicos de la ciudad. Estamos, pues, ante un interés mucho más orientado hacia la necesidad de conservar un determinado «status» privilegiado. El ejercicio de su condición de «señor» apoya también en la Baja Edad Media la cualidad de «noble» de que gozaron muchas ciudades y, por supuesto, Burgos, así como la pertenencia a ese «club» restringido de ciu-

${ }^{51}$ GUERRERO NAVARRETE, Y. (1985): Organización y Gobierno en Burgos durante el reinado de Enrique IV de Castilla (1453-1476).Madrid, y GUERRERO NAVARRETE, Y. (1989): «Aproximación a las relaciones campo-ciudad en la edad Media: el alfoz y el señorio burgales. Génesis y primer desarrollo». Historia. Instituciones y Documentos, Universidad de Sevilla, 16 $15-45$. 
dades inalienables con voz y voto en los acontecimientos y principales procesos políticos del reino.

Idénticamente conflictivas e igualmente abundantes en unas fuentes que poseen un carácter eminentemente judicial, son aquellas menciones a conflictos permanentes de tierras, vasallos o jurisdicción entre la ciudad y sus poderosos vecinos, en este caso y en lo que a Burgos respecta, fundamentalmente centrados en los vecinos eclesiásticos de la ciudad: obispado, Cardeña o las Huelgas. También han sido objeto de pormenorizados estudios que hacen innecesaria su exposición en este momento, máxime cuando, como antes mencioné, carecen de especial interés para el objetivo del presente trabajo al tratarse de meros incidentes vecinales sin mayor trascendencia para la honra y el «honor» urbanos.

Mayor interés han despertado para mi en los últimos años las dos últimas formas de relación elites urbanas/nobleza antes mencionadas. En trabajos previos abordé el problema de las alianzas y contra-alianzas que imponen, por un lado, la participación de las ciudades en la construcción del Estado Moderno peninsular y, por otro, la red clientelar que de arriba abajo y viceversa recorre el tejido social urbano y que es responsable de la mayor parte de las alteraciones del orden público en las ciudades castellanas de la Baja Edad Media ${ }^{52}$. Efectivamente, parece como si la vida cotidiana de la ciudad bajomedieval se viera continuamente sobresaltada por escaramuzas más o menos intensas y violentas, protagonizadas la mayor parte de las veces por hombres pertenecientes a la clientela de algún poderoso. Generalmente no provocan muertes y si algunos daños materiales, pero en ocasiones son el origen de largos períodos de inseguridad que afectan de forma importante a la convivencia y al conjunto de la comunidad. Aparentemente, estas luchas de bandos tienen diferentes causas en su origen, pero en todos los casos traducen un conflicto subyacente, bien de carácter horizontal bien de carácter vertical, entre las diferentes élites. Unas veces -como veremos-, adoptan como pretexto ciertos acontecimientos que se producen en la esfera de la alta política: los enfrentamientos banderizos entre los distintos sectores nobiliarios mueven también sus piezas a nivel local e implican a miembros de las élites urbanas, todos ellos vinculados en mayor o en menor medida a la clientela de alguna familia nobiliaria influyente. Otras, se liberan de cualquier disfraz para reflejar sin ambages las tensiones derivadas del difícil reparto del poder en el mundo urbano e implican, en unos casos, a individuos representativos de diferentes jurisdicciones (señorial, regia, eclesiástica), en otros a personas integrantes de la propia élite de poder de la ciudad.

52 GUERRERO NAVARRETE, Y. : «Redes clientelares en las estrategias de poder urbanas. Burgos, siglo XV». Comunicación presentada al congreso celebrado en Evora (2009) de la red CIDEHUS (en pubicación) y(2003-2004): «Orden público y corregidor en Burgos (siglo XV)». Anales de la Universidad de Alicante, 13, 59-102. 
Por consiguiente, las grandes luchas de la nobleza trastamarista o las ambiciones enfrentadas de las casas nobiliarias del entorno de una determinada ciudad alimentan en el siglo XV las violencias urbanas, justificando puntualmente ancestrales rivalidades privadas. Por ello, tanto cuando se trata de las repercusiones urbanas del auge o desgracia de algún alto personaje de la corte como cuando hablamos de escaramuzas entre hombres de un regidor y hombres del castillo, año tras año los «ruidos y bullicios» urbanos tienen los mismos protagonistas.

Mayor interés revierten para mí en ese momento las situaciones de alianza, cooperación y amistad entre las elites nobiliarias y urbanas. Menos estudiadas, constituyen un buen barómetro de la singularidad adquirida por los poderes urbanos en el conjunto de la sociedad política de la monarquía castellana bajomedieval. La documentación urbana conservada para este período hace referencia frecuentemente a «favores» especiales que la nobleza, cercana o no a los núcleos y elites urbanas, demanda constantemente de los gobiernos ciudadanos. En Burgos, la nobleza solicita perdón para delitos cometidos por sus allegados ${ }^{53}$, cargos y nombramientos -en su mayoría escribanías- con que beneficiar a sus continuos ${ }^{54}$, excepciones económicas y mercantiles ${ }^{55}$. A cambio, la ciudad se hará pagar dichos «favores»: en 1436, el condestable de Castilla es objeto de un regalo muy caro (100 doblas para un cobertor y paños por valor de $50.000 \mathrm{mrs}$. $\left.{ }^{56}\right)$ por «açelerar» ciertos pleitos en beneficio de Burgos, o, en ocasiones, se trata simplemente de reclamar la mediación e influencia a favor de la ciudad de algún poderoso cercano al monarca en casos especialmente delicados e importantes para Burgos ${ }^{57}$.

Sin duda, en este apartado el mejor ejemplo que podemos documentar en Burgos es el que afecta a las «cordiales» relaciones entre la ciudad y los Velasco. Considerado como el linaje nobiliario de mayor influencia en la ciudad, único poseedor de palacios y residencia en la ciudad del Arlanzón, nunca llegó a poseer en la misma recursos ni mecanismos de intervención directa en su gobierno a la manera que otros linajes, como por ejemplo los Mendoza en Guadalajara, poseyeron en otras ciudades. Ya he advertido con anterioridad que Burgos constituye un ejemplo claro de ciudad de realengo, poco o nada «nobilizada», donde la elite urbana mantuvo y conservó el control sobre los mecanismos de

\footnotetext{
${ }^{53}$ AMB, L.AA., 1388, fol. 79 ryv.

${ }^{54}$ AMB, LL.AA., 1411, fols. 23v, 27v, 1426-27, 18v, 1429-30, 11r y v, 13v y 14r, 22r, 28v, 1431-2-3, 19r, 1441, 85r y v, 1445-6-7, 98r.

${ }^{55}$ Ibid. 1429-30, 106v, 1441, 42v.

${ }^{56}$ Ibid. 1436, 47r,50ry 51r.

${ }^{57}$ Ibid. 1441, 44v, 46v y 47r.
} 
producción y reproducción del poder en la misma durante todo el período bajomedieval. Sin embargo, sí que se observa una presencia e influencia consentida e incluso buscada en algunos momentos especialmente delicados para la ciudad.

Las Actas del municipio burgalés están repletas de momentos, generalmente delicados para la situación del reino, frecuentemente de enfrenamiento entre el monarca y los nobles, en los que los condes de Haro se «ofreçen» a la ciudad, dado «que sus anteçesores habían sido naturales de ella» y como consecuencia de ello se hallan presentes en las sesiones de ayuntamiento o concejo ${ }^{58}$. Pero, el ejemplo mejor documentado a este respecto se produce en 1465, cuando con motivo de la rebelión de un sector de la nobleza -al que se ha unido en los meses finales de 1464 la propia ciudad de Burgos- el monarca, temiéndose una etapa conflictiva, que efectivamente desembocará al fin en la simbólica deposición del mismo en la llamada «Farsa de Ávila», envía con poderes extraordinarios al hijo del conde de Haro, Pedro de Velasco, a Burgos con el objeto de mantener la ciudad para la causa regia. El despliegue de los acontecimientos que precedieron y siguieron a este encargo ejemplifica perfectamente el carácter de las relaciones que siempre vincularon a las elites burgalesas con los Velasco.

Desde finales, del año 1464, las relaciones entre la elite burgalesa y el rey Enrique IV se han deteriorado a raíz de la participación activa de la ciudad en la reunión celebrada en Burgos que sanciona la rebelión nobiliaria contra el monarca y en las vistas de Cigales y Cabezón que darán lugar a la llamada Sentencia de Medina del Campo en abril de 1465 cuyo incumplimiento desembocará en la farsa de Ávila. El 18 de marzo hacía su entrada en Burgos Pedro de Velasco, portador de una carta de Enrique IV por la que se ordenaba a las autoridades ciudadanas la entrega inmediata en manos de éste de todos los puntos fuertes de la ciudad, al tiempo que les conminaba a prestarle ayuda, jurarle pleito homenaje y darle fe y creencia en todos los asuntos tocantes a la gobernación, administración y justicia ${ }^{59}$. Jamás se había producido en Burgos una ingerencia real de tanto calado, la pasividad con que la elite burgalesa la acepta de inmediato demuestra la delicada situación de la ciudad. Sin embargo, pese a la amplitud del mandato regio y a la pasividad de la ciudad, Pedro de Velasco garantiza a los oficiales de Burgos «actuar siempre de acuerdo con el consentimiento de las autoridades ciudadanas» (fols. 32 ryv). Aún mas, sólo unos meses más tarde, el 8 de junio, Pedro de Velasco, relataba en el ayuntamiento los acontecimientos que se estaban produciendo de la siguiente manera: «Luego don Pedro de Velasco les dixo en como sopiesen que el arçobispo de Toledo e el conde de Plasençia, Alvaro de Stuñiga, e

\footnotetext{
58 AMB. LL.AA., 1398, 78r, 79r yv, 81r, 1411, 1, 1421-2-3, 71v, 77v.

59 Ibid. 1465, fols. 29 ryv, 30 ryv y 31 r.
} 
el marques de Villena, don Juan Pacheco, e el maestre de Alcantara con los condes de Benavente e Paredes en la dehesa de Avila, çerca de Avila, avian fecho un cadahalso e posieron en el una estatua con una corona e una espada çeñida e un baston en la mano e bestida de seda negra e todo el estrado de seda, e que soviera el arçobispo de Toledo don Alonso Carrillo e le quitara la corona, el conde de Plasençia le deçeñiera la espada e el marques de Villena le quitara el baston e el conde de Paredes echara la estatua del cadahalso abaxo, e luego tocaren las tronpetas desiendo Castilla Castilla por el rey don Alonso, e que asi lo alçaran por rey, e demas de esto que era alçada Toledo por el dicho rey don Alonso, e Cordova e Avila e Medina e Valladolid, por ende que ge lo fasia saber para que viesen lo que esta çibdad devia faser e que ge lo dexava a su buena discreción, que el de alli les dava su fe que el seguiria e faria todo aquello que ellos les paresçiese que devia seguir e seria con ellos en todo ello» (fols.58 ryv). A ello la ciudad «tras fablar en ello muy largo por espaçio de dos oras... e non savian que deçir nin que non», contestó que «pues el dicho señor rey lo avia (a Pedro de Velasco) aquí enbiado con sus cartas de poderes, que ellos no podian levar otra mejor via salvo la que a el bien vista fuese, ca segund su descreçion e estado e linaje aquella creyan que era la mas buena que devian llevar» (fols. $59 \mathrm{r}$ yv). Finalmente, el 12 de junio don Pedro les hace partícipes de su inclinación por la causa de Alfonso. La ciudad todavía tardará un mes más en abrazar la causa de éste tras numerosos debates, convocatorias de las vecindades y, finalmente, un significativo y extenso pliego de condiciones que obligan a firmar al joven príncipe.

A modo de conclusión, pues, es factible afirmar que la relación, salpicada de consensos y conflictos, que define a los diferentes poderes a lo largo de todo el siglo XV, se torna un precioso instrumento de análisis de las estrategias por las cuales cada uno de dichos poderes busca reforzar su identidad política propia y su singularidad por sí mismo y por oposición a los contrarios. De ahí la importancia que proyecta hacia futuras investigaciones el análisis, apenas esbozado en la actualidad, de las relaciones entre la nobleza y las ciudades, de las diferentes ciudades entre si en el seno de territorios bien diferenciados, o del área de influencia de una determinada ciudad sobre los territorios cercanos que no forman parte de su jurisdicción directa. En este sentido, la investigación no ha hecho más que empezar, espero, por el momento, haber conseguido esbozar al menos los cimientos sobre los que se apoya en parte la «honorabilidad» de los habitantes de Burgos, vivos o muertos y, en definitiva, la imagen que esta ciudad presenta de sí misma, como un centro de poder, significado en y por el poder patricio, poseedor de un imaginario propio, singular con respecto a las demás ciudades y al conjunto de los poderes que conviven y comparten escenario dentro de la Monarquía Castellana. 